\title{
Características fenológicas, produtivas e qualitativas de híbridos de girassol em diferentes épocas de semeadura para produção de silagem ${ }^{1}$
}

\author{
Renius Mello², José Laerte Nörnberg ${ }^{3}$, João Restle ${ }^{4}$, Mikael Neumann ${ }^{5}$, Augusto César de \\ Queiroz $^{6}$, Patrícia Barcellos Costa ${ }^{2}$, André Luiz Rodrigues Magalhães ${ }^{7}$, Diego Bitencourt de David ${ }^{8}$
}

1 Parcialmente financiada pela FAPERGS.

2 Doutorando em Zootecnia da UFV, bolsista CNPq

3 Universidade Federal de Santa Maria.

4 Pesquisador Visitante CNPq - UFG.

5 UNICENTRO - PR.

${ }^{6}$ Universidade Federal de Viçosa.

${ }^{7}$ Faculdade de Medicina Veterinária - Universidade de Cuiabá

${ }^{8}$ Graduação em Zootecnia da UFSM.

RESUMO - Objetivou-se verificar o efeito de três épocas de semeadura - outubro (antecipada), novembro (normal) e dezembro (tardia) - sobre as características fenológicas, produtivas e qualitativas de quatro híbridos de girassol: Rumbosol-91 (forrageiro), M-734 (duplo propósito), C-11 (duplo propósito) e BRS-191 (granífero) destinados à produção de silagem. O delineamento experimental foi em blocos ao acaso, com arranjo fatorial 4 x 3 (quatro híbridos x três épocas de semeadura) e quatro repetições. A semeadura em outubro resultou em ciclo mais longo, altura de planta mais elevada e diâmetro e participação de capítulo menores, como conseqüência da temperatura, da insolação e do fotoperíodo, que foram mais baixos nessa época. Os híbridos Rumbosol-91 e BRS-191 semeados em novembro apresentaram taxas de acamamento mais quebramento maiores, de 49,6 e 65,7\%, respectivamente. Os híbridos BRS-191 e M-734 semeados em dezembro apresentaram produtividades de fitomassa maiores, com 39,71 e 43,76 t ha ${ }^{-1}$ de matéria verde e 11,31 e 11,41 t ha ${ }^{-1}$ de matéria seca, respectivamente. Nos constituintes da planta, os teores de PB aumentaram e os de FDN, FDA e LDA diminuíram, respectivamente, para colmo, folhas e capítulo. Na planta inteira, os teores de MS oscilaram de 23,2\%, para o híbrido Rumbosol-91 semeado em novembro, a 47,9\%, para o híbrido C-11 semeado em dezembro, indicando que os híbridos possuem capacidade diferenciada de retenção de umidade em estádio de maturidade fisiológica semelhante da cultura (fase R-9). Os teores de PB variaram de 7,0 a 15,7\%, demonstrando a riqueza protéica da cultura. Os teores de LDA da planta inteira oscilaram de 6,5 a 12,4\%, sendo que os híbridos M-734 semeado em dezembro e C-11 semeado em outubro apresentaram os teores mais baixos. Visando à produção de silagem de elevada qualidade, o híbrido M-734 semeado em dezembro apresentou melhor relação entre fenologia, produtividade e composição bromatológica.

Palavras-chave: capítulo, características agronômicas, Helianthus annuus, rendimento de fitomassa

\section{Sowing dates effects on the phenology, yield and qualitative traits of sunflower hybrids for silage making}

ABSTRACT - The objective of this study was to estimate the effect of three sowing dates: October (early), November (normal) and December (late), on the phenological, yield and qualitative traits of four sunflower hybrids: Rumbosol-91 (forage), M-734 (double purpose), C-11 (double purpose) and BRS-191 (grain) grown for silage making. A 4 x 3 factorial treatment combination (four hybrids $\mathrm{x}$ three sowing dates) was allocated in a randomized block design with four replications. The October sowing brought about longer cycle, higher plant height, and smaller seed head diameter and contribution due to the prevailing climatic conditions of lower temperature, insolation and photoperiod during the crop growth period. The Rumbosol-91 and BRS-191 hybrids sowed in November showed higher lodging plus stalk breaking proportion of about 49.6 and $65.7 \%$, respectively. The BRS-191 and M734 hybrids sowed in December showed higher biomass yields of 39.71 and $43.76 \mathrm{t} \mathrm{ha}^{-1}$ fresh matter and 11.31 and $11.41 \mathrm{t}$ ha $\mathrm{a}^{-1}$ drymatter, respectively. While the $\mathrm{CP}$ content increased, the NDF, ADF and ADL contents decreased from the stem, to the leaf and to the head plant fractions. The whole plant DM values ranged from $23.2 \%$ in the Rumbosol-91 hybrid sowed in November to $47.9 \%$ in the $\mathrm{C}-11$ hybrid sowed in December, indicating that the hybrids have differentiated moisture retention capacity at similar physiologic maturity of the culture (R-9 phase). The CP values ranged from 7.0 to $15.7 \%$, an evidence of the high protein content of the culture. The ADL values of the whole plant ranged among 6.5 to $12.4 \%$, with lowest values for the M- 734 hybrid sowed in December and C-11 hybrid sowed in October. The M-734 hybrid sowed in December has better relationship among phenology, yield and bromatological composition, traits required for the making of high quality silage.

Key Words: agronomic characteristics, biomass yield, head, Helianthus annuus 


\section{Introdução}

Na maioria das áreas agrícolas do mundo, períodos de intenso crescimento forrageiro alternam-se com períodos de baixa produção, seja por deficiência hídrica seja por quedas na temperatura e na luminosidade. Nesse contexto, uma das práticas para melhorar a alimentação do rebanho e minimizar os efeitos da redução de peso e/ou da produção de leite é a conservação de forragens na forma de silagem.

No Brasil, o girassol (Helianthus annuus, L.) tem sido objeto de muitas pesquisas na área da fisiologia vegetal, em razão do elevado potencial fotossintético, das altas taxas de crescimento, da capacidade em extrair e conduzir a água e dos movimentos diaeliotrópicos das folhas e do capítulo, porém, poucos estudos são feitos envolvendo a produção de girassol para ensilagem.

Tradicionalmente, o girassol é considerado uma cultura de grande plasticidade, pois se desenvolve bem em regiões de clima temperado, subtropical e tropical (Barni et al., 1995a). A dependência de fatores do meio e, portanto, a variabilidade em rendimento é outra característica importante da cultura. Segundo Santos et al. (2002), a otimização de eficiência produtiva é fundamental para reduzir os custos de produção. Vários fatores, incluindo época de semeadura, variabilidade genética, fertilidade do solo, disponibilidade de água, estádio de desenvolvimento da planta, número de plantas por unidade de área e suas interações, afetam a produtividade da cultura (Tomich et al., 2003). A investigação dos limites de produtividade visa identificar a contribuição das variáveis de ambiente responsáveis pelo desempenho final de determinado genótipo e ressaltar em que nível cada uma delas representa estrangulamento à expressão dessa produtividade (Barni et al., 1995b).

Ungaro et al. (2000) observaram que a época de semeadura influencia a produção de grãos e de seus componentes, sendo a interação época de semeadura $\times$ cultivar significativa para todos os caracteres avaliados, demonstrando a importância de se conhecer a resposta de um cultivar ante as variações ambientais. Em comparação ao milho e ao sorgo, a interação épocas de semeadura $\times$ genótipos de girassol tem sido pouco estudada no Brasil. Além disso, há grande variabilidade nas recomendações da melhor época de semeadura (Leite et al., 2005). Dependendo da região do país, a semeadura da cultura tem sido indicada desde o inverno-primavera até o verão-outono. De acordo com Marin et al. (2000), vários métodos podem ser empregados para determinação da época de semeadura mais adequada, seja por ensaios em campo avaliando variáveis biométricas da cultura seja simulações utilizando modelos agrometeorológicos de estimação da produtividade agrícola.

A qualidade da silagem está intimamente relacionada às características agronômicas das plantas forrageiras, o que torna de suma importância o estudo da relação das partes componentes de cada forrageira antes de indicar sua viabilidade para essa utilização (Banys et al., 1996). Do mesmo modo, Zago (1991) afirmou que, para se obter alta produção de fitomassa e elevado valor nutritivo da silagem, é necessário considerar a aptidão e o porte da planta, a proporção entre colmo, as folhas e os grãos, a suculência do colmo, entre outras características que variam muito entre os inúmeros materiais disponíveis no mercado.

Nesse contexto, objetivou-se avaliar as características fenológicas, produtivas e qualitativas de híbridos de girassol semeados em diferentes épocas visando à produção de silagem de elevada qualidade.

\section{Material e Métodos}

O ensaio de campo foi realizado no Setor de Bovinocultura de Corte do Departamento de Zootecnia (DZO) e as análises laboratoriais executadas no Núcleo Integrado de Desenvolvimento em Análises Laboratoriais (NIDAL) do Departamento de Tecnologia e Ciência dos Alimentos (DTCA), ambos da Universidade Federal de Santa Maria (UFSM), Santa Maria, RS. O local está fisiograficamente situado na Depressão Central do estado do Rio Grande do Sul, à altitude de $95 \mathrm{~m}$, paralelo de $29^{\circ} 43^{\prime}$ latitude sul e meridiano de $53^{\circ} 42^{\prime}$ longitude oeste de Greenwich (Brasil, 1973). O experimento foi conduzido no período de outubro de 2001 a agosto de 2002.

O clima da região é Cfa (subtropical úmido), conforme classificação de Köppen, com possibilidade de estiagem no verão, tendo precipitação média anual entre 1.300 e $1.800 \mathrm{~mm}$ e mensais de 90 a $190 \mathrm{~mm}$, temperatura média anual de $19,2^{\circ} \mathrm{C}$, com média mínima de $9,3^{\circ} \mathrm{C}$ em julho e média máxima de $24,7^{\circ} \mathrm{C}$ em janeiro, insolação de 2.212 horas anuais e umidade relativa do ar de $82 \%$ (Moreno, 1961). O solo é classificado como Argissolo Vermelho Distrófico arênico (Embrapa, 1999) e pertence à unidade de mapeamento São Pedro. A adubação de base foi executada conforme recomendação da Comissão de Fertilidade do Solo-RS/SC (1995), sendo constituída por $450 \mathrm{~kg} \mathrm{ha}^{-1}$ da fórmula 10-18-20 acrescida de $11 \mathrm{~kg} \mathrm{ha}^{-1} \mathrm{de}$ bórax. Os resultados da análise de rotina de fertilidade de amostras de terra retiradas na camada de 0 a $20 \mathrm{~cm}$, revelaram: textura $=4$; argila $=25 \% ; \mathrm{pH} \mathrm{em} \mathrm{H}_{2} \mathrm{O}(1: 1)=5,1$; índice $\mathrm{SMP}=5,4 ; \mathrm{P}=21,3 \mathrm{mg} / \mathrm{dm}^{3} ; \mathrm{K}^{+}=34 \mathrm{mg} / \mathrm{dm}^{3} ; \mathrm{MO}=2,8 \%$; $\mathrm{Al}^{+3}=1,3 \mathrm{~mol}_{\mathrm{c}} / \mathrm{dm}^{3} ; \mathrm{Ca}^{+2}=3,8 \mathrm{cmol}_{\mathrm{c}} / \mathrm{dm}^{3} ; \mathrm{Mg}^{+2}=1,3 \mathrm{cmol}_{\mathrm{c}} / \mathrm{dm}^{3} ;$ CTC efetiva $=6,5 \mathrm{cmol}_{\mathrm{c}} / \mathrm{dm}^{3}$ e saturação de bases $=46 \%$. 
Os tratamentos foram compostos por quatro híbridos de girassol(Rumbosol-91, M-734, C-11 eBRS-191, Tabela 1)e três épocas de semeadura: 3 o decêndio de outubro (26/10/2001) semeadura antecipada; 3 - decêndio de novembro $(21 / 11 / 2001)$ - semeadura normal; e 3 o decêndio de dezembro (23/12/2001) - semeadura tardia em relação ao cultivo principal da região.

As variáveis analisadas foram: ciclo (dias da semeadura à colheita), altura de planta $(\mathrm{m})$, diâmetro de capítulo $(\mathrm{cm})$, plantas acamadas mais quebradas (\%), contribuição percentual de colmo, folhas e capítulo (receptáculo mais aquênios), produção de biomassa verde e seca $\left(\mathrm{t} \mathrm{ha}^{-1}\right)$ e composição bromatológica da planta inteira e de seus constituintes.

O cultivo foi feito em parcelas de 7,0 $\mathrm{m}$ de comprimento por $5,0 \mathrm{~m}$ de largura $\left(35 \mathrm{~m}^{2}\right)$, com sete linhas espaçadas a $0,70 \mathrm{~m}$. Nas avaliações, para se retirar o efeito de bordadura, foram utilizadas as cinco linhas centrais, desprezando-se $0,50 \mathrm{~m}$ das extremidades como área útil de cada parcela $\left(21 \mathrm{~m}^{2}\right)$. As sementes foram tratadas com inseticida à base de Furathiocarb e as parcelas semeadas manualmente, tendo a emergência ocorrida entre 7 e 14 dias pós-semeadura. $\mathrm{O}$ desbaste foi feito, em média, 30 dias pós-semeadura deixando-se quatro plantas por metro linear, visando ao ajuste da população final em, aproximadamente, $57 \mathrm{mil}$ plantas por hectare. A adubação em cobertura foi realizada quando as plantas apresentavam sete folhas, com $60 \mathrm{~kg} \mathrm{ha}^{-1}$ de $\mathrm{N}$ na forma de sulfato de amônio. Durante a condução do ensaio, foi realizada uma capina e duas aplicações de inseticida à base de Lambdacialotrina, mediante laudo técnico das lavouras.

$\mathrm{Na}$ fase em que os capítulos estavam voltados para baixo e com a parte posterior amarelada, as brácteas com coloração castanha, os aquênios no ponto farináceo e as folhas basais senescidas (fase R-9), as plantas da área útil foram avaliadas quanto ao acamamento mais quebramento e cortadas a $20 \mathrm{~cm}$ de altura do solo, para obtenção das produções de matéria verde (PMV) e matéria seca (PMS). Foram amostradas 15 plantas representativas da população, para avaliação da altura de planta e do diâmetro de capítulo, e dessas, cinco para separação dos constituintes morfológicos da planta.

As amostras foram secas em estufa com circulação forçada, a $55 \pm 5^{\circ} \mathrm{C}$ até peso constante, e trituradas em moinho estacionário do tipo Thomas Wiley, em peneiras com crivos de $1 \mathrm{~mm}$. Nesse material, foram realizadas, em duplicata, as seguintes análises bromatológicas: MS, MO e PB conforme AOAC (1995); componentes da parede celular, fibra em detergente neutro (FDN), de acordo com Van Soest et al. (1991), sem sulfito de sódio e com a enzima alfa-amilase termoestável Termamyl $120 \mathrm{~L}^{\circledR}$ (Novozymes Latin America Ltda.); fibra em detergente ácido (FDA) e lignina em detergente ácido (LDA), segundo Goering \& Van Soest (1970). As análises de FDN, FDA e LDA foram realizadas em cadinhos de vidro borossilicado com placa de vidro sinterizada de porosidade $n^{\circ} .2$ (Schott-Duran ${ }^{\circledR}$, Schott Germany, Inc.).

O delineamento experimental foi em blocos casualizados, em arranjo fatorial $4 \times 3$ (quatro híbridos de girassol x três épocas de semeadura), com quatro repetições, conforme o modelo estatístico:

$$
\mathrm{Y}_{\mathrm{ijk}}=\mu+\alpha_{\mathrm{i}}+\beta_{\mathrm{j}}+(\alpha \beta)_{\mathrm{ij}}+\gamma_{\mathrm{k}}+\varepsilon_{\mathrm{ijk}}
$$

em que $\mathrm{Y}_{\mathrm{ijk}}$ é o valor observado no i-ésimo híbrido na j-ésima época de semeadura no k-ésimo bloco; $\mu$, a média geral da variável; $\alpha_{\mathrm{i}}$, o efeito do i-ésimo híbrido; $\beta_{\mathrm{j}}$, o efeito da j-ésima época de semeadura; $(\alpha \beta)_{\mathrm{ij}}$, o efeito da interação entre i-ésimo híbrido e j-ésima época de semeadura; $\gamma_{\mathrm{k}}$, o efeito do k-ésimo bloco; $\varepsilon_{\mathrm{ijk}}$, o efeito aleatório associado à observação pressuposto NID $\left(0, \sigma^{2}\right)$.

Os dados foram submetidos à análise de variância pelo procedimento de Modelos Lineares Gerais (PROC GLM) e suas médias comparadas pelo teste Tukey a 5\% de probabilidade, utilizando-se o programa estatístico SAS (1999).

\section{Resultados e Discussão}

Os dados agrometeorológicos referentes ao período experimental podem ser visualizados na Tabela 2.

Tabela 1 - Características agronômicas de diferentes híbridos simples de girassol (Helianthus annuus L.)

Table 1 - Agronomic characteristics of different sunflower (Helianthus annuus L.) single-cross hybrids

\begin{tabular}{|c|c|c|c|c|c|}
\hline $\begin{array}{l}\text { Híbrido } \\
\text { Hybrid }\end{array}$ & $\begin{array}{l}\text { Empresa } \\
\text { Company }\end{array}$ & $\begin{array}{l}\text { Aptidão } \\
\text { Aptitude }\end{array}$ & $\begin{array}{l}\text { Ciclo } \\
\text { Cycle }\end{array}$ & $\begin{array}{l}\text { Porte } \\
\text { Size }\end{array}$ & $\begin{array}{l}\text { Coloração dos aquênios } \\
\text { Color of achenes }\end{array}$ \\
\hline Rumbosol-91 & Sinuelo Agropecuária & $\begin{array}{l}\text { Forrageiro } \\
\text { Forage }\end{array}$ & $\begin{array}{l}\text { Tardio } \\
\text { Late }\end{array}$ & $\begin{array}{l}\text { Alto } \\
\text { High }\end{array}$ & $\begin{array}{l}\text { Preto } \\
\text { Black }\end{array}$ \\
\hline$M-734$ & $\begin{array}{l}\text { Morgan-Mycogen/ } \\
\text { Dow Agrosciences }\end{array}$ & $\begin{array}{l}\text { Duplo propósito } \\
\text { Double purpose }\end{array}$ & $\begin{array}{l}\text { Precoce } \\
\text { Precocious }\end{array}$ & $\begin{array}{l}\text { Médio } \\
\text { Medium }\end{array}$ & $\begin{array}{l}\text { Marrom com estrias claras } \\
\text { Brown with clear stripes }\end{array}$ \\
\hline $\mathrm{C}-11$ & Cargill/Monsanto & $\begin{array}{l}\text { Duplo propósito } \\
\text { Double purpose }\end{array}$ & $\begin{array}{l}\text { Semi-precoce } \\
\text { Semi-precocious }\end{array}$ & $\begin{array}{l}\text { Médio } \\
\text { Medium }\end{array}$ & $\begin{array}{l}\text { Marrom com estrias claras } \\
\text { Brown with clear stripes }\end{array}$ \\
\hline BRS-191 & Agromen/Embrapa & $\begin{array}{l}\text { Granífero } \\
\text { Grain }\end{array}$ & $\begin{array}{l}\text { Precoce } \\
\text { Precocious }\end{array}$ & $\begin{array}{l}\text { Médio } \\
\text { Medium }\end{array}$ & $\begin{array}{l}\text { Preto com estrias cinzas } \\
\text { Black with gray stripes }\end{array}$ \\
\hline
\end{tabular}


As características fenológicas dos híbridos de girassol semeados em diferentes épocas são apresentadas na Tabela 3. Os híbridos M-734 e BRS-191 tenderam a apresentar ciclo mais precoce que o Rumbosol-91 e o C-11, confirmando a característica agronômica dos materiais descrita na Tabela 1. Observa-se ainda que o ciclo da cultura tendeu a diminuir da semeadura em outubro para dezembro, como resultado do aumento da temperatura e da insolação média diária no mesmo período (Tabela 2), o que está de acordo com a afirmativa de Silva \& Mundstock (1990) de que a duração total do ciclo diminui à medida que a época de semeadura atrasa de agosto para novembro. Avaliando o crescimento de cultivares de girassol semeados na safra (outubro) e safrinha (fevereiro) em região tropical, Fonseca et al. (2000) observaram que a semeadura na safrinha alongou o ciclo de 76 para 103 dias, reduziu a altura média da planta de 1,72 para 1,32 m e diminuiu o diâmetro médio de capítulo de 28,5 para $20 \mathrm{~cm}$ e a produção de MS de 5,2 para 3,7 t ha- ${ }^{-1}$ no estádio de maturação física dos híbridos C-11 e M-9207. Todavia, ressalta-se que a semeadura em fevereiro foi mais tardia que a última desse estudo (dezembro) e que, provavelmente, a temperatura e insolação foram menores durante o ciclo da cultura. Dessa forma, infere-se que o aumento da temperatura e na luminosidade diminui a duração do ciclo, ou seja, a taxa de crescimento da cultura está positivamente correlacionada à temperatura e à insolação. Além disso, o girassol atinge a maturidade fisiológica geralmente entre 85 e 100 dias pós-emergência, sendo 20 a 30 dias mais precoce que as culturas de milho e sorgo (Demarchi, 2000), liberando a área cultivada mais cedo e maximizando o uso da terra, uma vez que o fator tempo de ocupação da terra é considerado no cálculo em termos de produtividade (Ungaro et al., 2000).

Houve efeito da interação $(\mathrm{P}<0,05)$ épocas de semeadura $\times$ híbridos sobre a altura de planta, o diâmetro de capítulo e o acamamento mais quebramento. A altura de planta oscilou entre 1,15 e 1,79 m, com resultados superiores aos encontrados por Mello et al. (2004), na mesma região fisiográfica $(1,02 \mathrm{~m})$, e inferiores aos obtidos por Tomich et al. (2003), em região tropical média (2,05 m). O híbrido Rumbosol-91 semeado em novembro apresentou menor e o híbrido BRS-191 semeado em outubro maior altura de planta.

A variação do diâmetro de capítulo foi de 12,9 a 20,0 cm, estando dentro da média $(17,3 \mathrm{~cm})$ obtida por Tomich et al. (2003). O diâmetro de capítulo foi maior no híbrido Rumbosol91 semeado em dezembro e menor no híbrido BRS-191 semeado em outubro. O fato de o híbrido granífero BRS-191 ter apresentado menor diâmetro médio de capítulo e maior altura média de planta em relação ao híbrido forrageiro Rumbosol-91 demonstra a grande diversidade genética entre os híbridos de girassol disponíveis no mercado, tornando essencial a realização de estudos que evidenciem essas características, pois poderão nortear a escolha do cultivar em determinada região. Adicionalmente, verifica-se que, da semeadura realizada em outubro para a de dezembro, houve acréscimo no diâmetro de capítulo. De acordo com Zaffaroni \& Grigolo (1998), a característica fototrópica da cultura permite que a produtividade dos genótipos de girassol seja influenciada pelo comprimento do dia e pela densidade do fluxo de radiação solar na superfície. Os autores relataram ainda que a redução da luminosidade em 5,3 h/dia acarreta drástica redução no diâmetro de capítulo e nas medidas que definem caracteres agronômicos. Desse modo, o aumento no diâmetro de capítulo obtido nesse estudo pode ser justificado pelo aumento no fotoperíodo de outubro para dezembro. Os valores de altura de planta e diâmetro de capítulo encontrados nesse trabalho foram inferiores aos observados por Banys et al. (1996), de 3,61 m de altura e 28 a $38 \mathrm{~cm}$ de diâmetro de capítulo, em consórcio de girassol com milho em região tropical alta e semeadura no segundo decêndio de novembro. Assim, deduz-se que o girassol, mesmo sendo uma espécie do tipo $\mathrm{C}_{3}$, apresenta comportamento de espécies $\mathrm{C}_{4}$, pois responde positivamente a incrementos de temperatura e luminosidade na altura de planta e no diâmetro de capítulo.

Tabela 2 - Dados agrometeorológicos durante o período experimental

Table 2 - Agrometeorological data during the experimental period

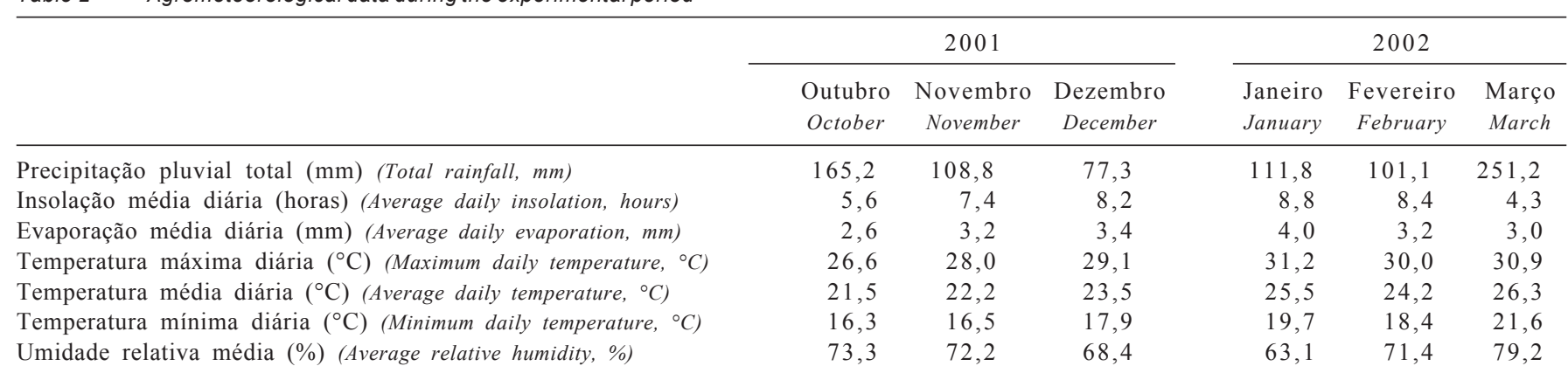

Fonte (Source): Estação Climatológica da Universidade Federal de Santa Maria. 
Tabela 3 - Dados fenológicos de híbridos de girassol (Helianthus annuus L.) semeados em diferentes épocas

Table 3 - $\quad$ Phenological data of sunflower hybrids (Helianthus annuus L.) sowed in different dates

\begin{tabular}{|c|c|c|c|c|}
\hline \multirow[t]{2}{*}{$\begin{array}{l}\text { Híbrido } \\
\text { Hybrid }\end{array}$} & \multicolumn{3}{|c|}{$\begin{array}{c}\text { Época de semeadura } \\
\text { Seeding date }\end{array}$} & \multirow[t]{2}{*}{$\begin{array}{c}\text { Média } \\
\text { Mean }\end{array}$} \\
\hline & $\begin{array}{l}\text { Outubro } \\
\text { October }\end{array}$ & $\begin{array}{l}\text { Novembro } \\
\text { November }\end{array}$ & $\begin{array}{c}\text { Dezembro } \\
\text { December }\end{array}$ & \\
\hline
\end{tabular}

\begin{tabular}{lcccc}
\hline \multicolumn{5}{c}{$\begin{array}{c}\text { Ciclo (dias) } \\
\text { Cycle (days) }\end{array}$} \\
Rumbosol-91 & 99 & 94 & 97 & 97 \\
M-734 & 95 & 94 & 90 & 93 \\
C-11 & 99 & 94 & 97 & 97 \\
BRS-191 & 95 & 94 & 90 & 93 \\
Média & 97 & 94 & 93 & - \\
Mean & & & &
\end{tabular}

Altura de planta $(\mathrm{m})$

Plant height $(m)$

$\begin{array}{llllc}\text { Rumbosol-91 } & 1,73^{\mathrm{Aab}} & 1,15^{\mathrm{Cc}} & 1,59^{\mathrm{Ba}} & 1,49 \\ \text { M-734 } & 1,70^{\mathrm{Ab}} & 1,18^{\mathrm{Cbc}} & 1,33^{\mathrm{Bc}} & 1,40 \\ \text { C-11 } & 1,67^{\mathrm{Ab}} & 1,22^{\mathrm{Cb}} & 1,42^{\mathrm{Bb}} & 1,44 \\ \text { BRS-191 } & 1,79^{\mathrm{Aa}} & 1,44^{\mathrm{Ca}} & 1,64^{\mathrm{Ba}} & 1,62 \\ \text { Média } & 1,72 & 1,25 & 1,50 & \mathrm{CV}^{2}=8,7 \\ \text { Mean } & & & & \end{array}$

Diâmetro de capítulo $(\mathrm{cm})$

Head diameter $(\mathrm{cm})$

\begin{tabular}{|c|c|c|c|c|}
\hline Rumbosol-91 & $14,6^{\mathrm{Ba}}$ & $15,3^{\mathrm{Bab}}$ & $20,0^{\mathrm{Aa}}$ & 16,6 \\
\hline M-734 & $13,2^{\mathrm{Cbc}}$ & $15,2^{\mathrm{Bab}}$ & $18,5^{\mathrm{Ab}}$ & 15,6 \\
\hline$C-11$ & $14,0^{\mathrm{Cab}}$ & $15,9^{\mathrm{Ba}}$ & $17,7^{\mathrm{Ab}}$ & 15,9 \\
\hline BRS-191 & $12,9^{\mathrm{Bc}}$ & $14,0^{\mathrm{Bb}}$ & $16,4^{\mathrm{Ac}}$ & 14,4 \\
\hline Média & 13,7 & 15,1 & 18,1 & $C V^{2}=14,9$ \\
\hline \multicolumn{5}{|l|}{ Mean } \\
\hline \multirow{2}{*}{\multicolumn{5}{|c|}{$\begin{array}{l}\text { Acamamento mais quebramento (\%) } \\
\text { Lodging plus stalk breaking (\%) }\end{array}$}} \\
\hline & & & & \\
\hline Rumbosol-91 & $23,0^{\mathrm{Ba}}$ & $49,6^{\mathrm{Aab}}$ & $08,7^{\mathrm{Ba}}$ & 27,1 \\
\hline M-734 & $01,5^{\mathrm{Ac}}$ & $17,6^{\mathrm{Ac}}$ & $17,2^{\mathrm{Aa}}$ & 12,1 \\
\hline C-1 1 & $08,9^{\mathrm{Bbc}}$ & $27,6^{\mathrm{Abc}}$ & $04,3^{\mathrm{Ba}}$ & 13,6 \\
\hline BRS-191 & $19,1^{\mathrm{Bab}}$ & $65,7^{\mathrm{Aa}}$ & $12,6^{\mathrm{Ba}}$ & 32,5 \\
\hline Média & 13,1 & 40,1 & 10,7 & $C V^{2}=49,0$ \\
\hline Mean & & & & \\
\hline
\end{tabular}

${ }^{1}$ Não analisado estatisticamente; ${ }^{2}$ CV $(\%)=$ Coeficiente de variação. Médias seguidas por letras maiúsculas distintas na mesma linha e por letras minúsculas distintas na mesma coluna diferem $(P<0,05)$, respectivamente, entre épocas de semeadura e híbridos pelo teste Tukey.

${ }^{1}$ Not statistically analyzed: ${ }^{2} \mathrm{CV}(\%)=$ Coefficient of variation

Means followed by different capital letters in the same line and by different small letters in the same column differ $(P<0.05)$, respectively, among seeding dates and hybrids by Tukey test.

Analisando o acamamento mais quebramento, observa-se que os híbridos BRS-191 e Rumbosol-91 semeados em novembro apresentaram maior acamamento mais quebramento, provavelmente em razão da menor densidade de raízes e da menor resistência do colmo desses genótipos. Investigando a porcentagem de plantas acamadas e quebradas na semeadura de safrinha (fevereiro), Tomich et al. (2003) notaram menores problemas, com maior quebramento médio $(2,2 \%)$ que acamamento $(0,4 \%)$, de modo que a maior porcentagem de quebra também foi encontrada para o híbrido Rumbosol-91 (14,6\%) e justificada pela sua maior altura, o que não ocorreu nesse estudo. Rezende et al. (2003) observaram, em média, 8 a $15 \%$ de acamamento em seis cultivares de girassol, respectivamente, para densidades de 40 e 60 mil plantas por hectare. Esses autores mencionaram ainda que a maior tolerância a doenças causadas por fungos, como Alternaria spp. e Sclerotinia spp., favorece a redução de plantas acamadas. Dudienas et al. (1998) mencionaram que a alternariose pode provocar perdas de até $50 \%$ na cultura, como resultado da ausência de genes associados à resistência e à baixa eficiência dos fungicidas. Estudando o efeito da época de semeadura sobre a incidência de doença (alternaria) nos trópicos, esses autores verificaram que a semeadura realizada em agosto apresentou menor contaminação, promovida pelas condições climáticas (baixa umidade e temperatura) impróprias ao desenvolvimento da doença. Adicionalmente, Demarchi (2000) relatou que a semeadura em épocas normais aumenta os riscos fitossanitários e o acamamento, em decorrência da posição do capítulo na extremidade superior da planta. Nesse estudo, não foi avaliada a resistência a doenças, mas verificou-se a presença de manchas de Alternaria em todas as épocas de semeadura. Logo, os híbridos BRS-191 e Rumbosol-91 podem ter menor tolerância a doenças, as quais podem também contribuir para aumento do acamamento mais quebramento na semeadura em novembro.

A contribuição dos componentes morfológicos da planta foi influenciada $(\mathrm{P}<0,05)$ pela interação épocas de semeadura $\times$ híbridos avaliados (Tabela 4). A participação de colmo na planta inteira variou de 20 a $36,9 \%$, de modo que os híbridos Rumbosol-91, M-734 e C-11 semeados em novembro apresentaram menores contribuições.

O híbrido C-11 semeado em dezembro apresentou menor proporção de folhas (entre 2,8 e 22,2\%). Por outro lado, o híbrido C-11 semeado em dezembro apresentou maior contribuição de capítulo, cuja variação foi de 44,5 a $68,8 \%$. O incremento na participação de capítulo da semeadura realizada em outubro para dezembro (Tabela 4) foi diretamente proporcional ao aumento no diâmetro de capítulo (Tabela 3). Contribuições semelhantes às desse estudo foram obtidas por Mello et al. (2004) na mesma região fisiográfica, com semeadura realizada em novembro, cujos valores variaram de 24 a $27 \%$, de 17 a $23 \%$ e de 51 a $59 \%$, e por Tomich et al. (2003) nos trópicos, com semeadura realizada em fevereiro, cujos valores variaram de 28,7 a $38,6 \%$, de 15,8 a $25 \%$ e de 36,4 a $51,6 \%$, respectivamente, para colmo, folhas e capítulo. Os autores relataram ainda que a determinação da proporção dessas frações na planta constitui parâmetro importante na avaliação de genótipos 
Tabela 4 - Proporção dos componentes morfológicos da planta de híbridos de girassol (Helianthus annuus L.) semeados em diferentes épocas

Table 4 - Proportion of the morphologic components of the plant of sunflower hybrids (Helianthus annuus L.) sowed in different dates

\begin{tabular}{|c|c|c|c|c|}
\hline \multirow[t]{2}{*}{$\begin{array}{l}\text { Híbrido } \\
\text { Hybrid }\end{array}$} & \multicolumn{3}{|c|}{$\begin{array}{c}\text { Época de semeadura } \\
\text { Seeding date }\end{array}$} & \multirow[t]{2}{*}{$\begin{array}{l}\text { Média } \\
\text { Mean }\end{array}$} \\
\hline & $\begin{array}{l}\text { Outubro } \\
\text { October }\end{array}$ & $\begin{array}{l}\text { Novembro } \\
\text { November }\end{array}$ & $\begin{array}{c}\text { Dezembro } \\
\text { December }\end{array}$ & \\
\hline \multicolumn{5}{|c|}{$\begin{array}{c}\text { Colmo (\% na MS) } \\
\text { Stem }(\% \text { in DM) }\end{array}$} \\
\hline Rumbosol-91 & $33,2^{\mathrm{Aa}}$ & $20,0^{\mathrm{Bb}}$ & $30,3^{\mathrm{Aa}}$ & 27,8 \\
\hline M-734 & $33,9^{\mathrm{Aa}}$ & $21,4^{\mathrm{Bb}}$ & $26,5^{\mathrm{Ba}}$ & 27,3 \\
\hline C- 11 & $35,0^{\mathrm{Aa}}$ & $25,5^{\mathrm{Bb}}$ & $28,4^{\mathrm{Ba}}$ & 29,6 \\
\hline BRS-191 & $36,9^{\mathrm{Aa}}$ & $34,7^{\mathrm{Aa}}$ & $34,2^{\mathrm{Aa}}$ & 35,3 \\
\hline Média & 34,7 & 25,4 & 29,8 & $\mathrm{CV}^{1}=9,5$ \\
\hline
\end{tabular}

Folhas (\% na MS)

Leaves (\% in DM)

$\begin{array}{llllc}\text { Rumbosol-91 } & 22,2^{\mathrm{Aa}} & 21,8^{\mathrm{Aa}} & 04,8^{\mathrm{Bab}} & 16,3 \\ \text { M-734 } & 18,6^{\mathrm{Aab}} & 14,3^{\mathrm{Ab}} & 14,5^{\mathrm{Aa}} & 15,8 \\ \text { C-11 } & 17,3^{\mathrm{Aab}} & 15,0^{\mathrm{Aab}} & 02,8^{\mathrm{Bb}} & 11,7 \\ \text { BRS-191 } & 13,4^{\mathrm{Ab}} & 14,7^{\mathrm{Ab}} & 13,9^{\mathrm{Aa}} & 14,0 \\ \text { Média } & 17,9 & 16,5 & 09,0 & \mathrm{CV}^{1}=19,4 \\ \text { Mean } & & & & \end{array}$

Capítulo (\% na MS)

Head (\% in DM)

$\begin{array}{llllc}\text { Rumbosol-91 } & 44,5^{\mathrm{Ba}} & 58,2^{\mathrm{Aa}} & 64,9^{\mathrm{Aab}} & 55,9 \\ \text { M-734 } & 47,5^{\mathrm{Ba}} & 64,3^{\mathrm{Aa}} & 59,0^{\mathrm{Ab}} & 56,9 \\ \text { C-11 } & 47,7^{\mathrm{Ca}} & 59,4^{\mathrm{Ba}} & 68,8^{\mathrm{Aa}} & 58,6 \\ \text { BRS-191 } & 49,7^{\mathrm{Aa}} & 50,6^{\mathrm{Aa}} & 51,9^{\mathrm{Ac}} & 50,7 \\ \text { Média } & 47,3 & 58,1 & 61,1 & \mathrm{CV}^{1}=6,5 \\ \text { Mean } & & & & \end{array}$

${ }^{1} \mathrm{CV}(\%)=$ Coeficiente de variação.

Médias seguidas por letras maiúsculas distintas na mesma linha e por letras minúsculas distintas na mesma coluna diferem $(P<0,05)$, respectivamente, entre épocas de semeadura e híbridos pelo teste Tukey.

${ }^{1} \mathrm{CV}(\%)=$ Coefficient of variation

Means followed by different capital letters in the same row and by different small letters in the same column differ $(P<0.05)$, respectively, among seeding dates and hybrids by Tukey test.

de girassol para a ensilagem, sendo preferível aquele com porcentagem menor de caule e maior de folhas e de capítulo.

Referenciando-se à cultura do milho, Nussio (1991) definiu que a planta ideal para a produção de silagem de alta qualidade deve apresentar em sua constituição $22 \%$ de colmo, $14 \%$ de folhas e $64 \%$ de espiga. Nesse caso, o híbrido de girassol M-734 semeado em novembro estaria dentro do recomendado. Contudo, sugere-se que os genótipos de girassol destinados à produção de silagem de alta qualidade devem possuir de 20 a $25 \%$ de colmo com melhor qualidade de fibra, de 20 a $25 \%$ de folhas e de 50 a $60 \%$ de capítulo com menor retenção de água e concentração moderada de óleo, a fim de não prejudicar o processo fermentativo, a ingestão de matéria seca, a digestibilidade da fibra e, conseqüentemente, o desempenho animal. Assim, a fitomassa do híbrido
Rumbosol-91 semeado em novembro apresentou melhor proporção entre os componentes morfológicos da planta e, portanto, entre os híbridos estudados, é que possivelmente resultaria em silagem de melhor qualidade.

As produtividades de matéria verde (PMV) e seca (PMS) podem ser visualizadas na Tabela 5. Houve efeito $(\mathrm{P}<0,05)$ da interação épocas de semeadura $\times$ híbridos. Os híbridos M-734 e BRS-191 semeados em dezembro apresentaram maiores PMV e PMS e, abstraindo-se os riscos de estiagens em janeiro e fevereiro e considerando somente o item produtividade, parecem ser os mais indicados para a produção de silagem.

Segundo Tosi et al. (1975), as produções de MS dessa espécie variam de 4,43 a 5,88 tha ${ }^{-1}$, o que permite classificá-la como de baixa produtividade, em virtude de seus menores teores de MS (15 a 23\%). Em revisão, Evangelista \& Lima (2001) relataram rendimentos de 12 a 48 tha $^{-1}$ PMV e 4 a 12 tha ${ }^{-1}$ PMS, influenciadas pela densidade de semeadura, pela idade de colheita e pelo cultivar.

No estado de São Paulo, mudando apenas o cultivar utilizado, Ungaro et al. (2000) recomendaram distintas épocas de semeadura em termos de rendimento de aquênios e fitomassa: janeiro para o IAC-Anhandy; julho e agosto para o VNIIMK; e, em janeiro e junho para o Contisol 621. Entretanto, Silva \& Mundstock (1990) afirmaram que a resposta do girassol em rendimento de grãos, conforme a época de semeadura, não está relacionada à precipitação durante a estação de crescimento ou ao híbrido utilizado, mas sim aos fatores de ambiente mais ou menos favoráveis para o desenvolvimento de seus patógenos. Avaliando o efeito da deficiência hídrica no rendimento de cultivares de girassol semeados em 36 épocas no estado de São Paulo, Marin et al. (2000) recomendaram a semeadura entre 11 de outubro e 1 o de dezembro, em Piracicaba e Ribeirão Preto, e entre 21 de setembro e 11 de janeiro, em Manduri. Estudando o efeito de duas épocas de semeadura ( 3 o decêndio de julho e $2^{\mathrm{o}}$ decêndio de setembro) em três cultivares de girassol (Contisol 711, Dekalb 180 e GR 10) no estado do Rio Grande do Sul, Silva \& Rizzardi (1993) relataram que a introdução do girassol como primeira cultura em um sistema de sucessão é uma alternativa viável quando se utilizam cultivares de ciclo curto e, em regiões específicas, caracterizadas por temperaturas mais elevadas e maior estação de crescimento, possibilitando antecipação da colheita e semeadura em sucessão das culturas de verão na época principal. Santos et al. (2002) também observaram grande variação na resposta de cultivares de girassol ao fator tempo.

De acordo com Fageria (1989), a variabilidade genética das plantas refere-se às características hereditárias de uma 
Tabela 5 - Produção de matéria verde (PMV) e seca (PMS) de híbridos de girassol (Helianthus annuus L.) semeados em diferentes épocas

Table 5 - Fresh (FMY) and dry matter yield (DMY) of sunflower hybrids (Helianthus annuus L.) sowed in different dates

\begin{tabular}{|c|c|c|c|c|}
\hline \multirow[t]{2}{*}{$\begin{array}{l}\text { Híbrido } \\
\text { Hybrid }\end{array}$} & \multicolumn{3}{|c|}{$\begin{array}{c}\text { Época de semeadura } \\
\text { Seeding date }\end{array}$} & \multirow[t]{2}{*}{$\begin{array}{l}\text { Média } \\
\text { Mean }\end{array}$} \\
\hline & $\begin{array}{l}\text { Outubro } \\
\text { October }\end{array}$ & $\begin{array}{l}\text { Novembro } \\
\text { November }\end{array}$ & $\begin{array}{l}\text { Dezembro } \\
\text { December }\end{array}$ & \\
\hline \multicolumn{5}{|c|}{$\begin{array}{c}\operatorname{PMV}\left(\mathrm{t} \mathrm{ha}^{-1}\right) \\
F M Y\left(t h a^{-1}\right)\end{array}$} \\
\hline Rumbosol-91 & $18,66^{\mathrm{Aa}}$ & $19,09^{\mathrm{Aa}}$ & $11,70^{\mathrm{Bb}}$ & 16,48 \\
\hline M-734 & $17,16^{\mathrm{Ba}}$ & $19,12^{\mathrm{Ba}}$ & $43,76^{\mathrm{Aa}}$ & 26,68 \\
\hline C-11 & $16,12^{\mathrm{Aab}}$ & $20,17^{\mathrm{Aa}}$ & $7,22^{\mathrm{Bb}}$ & 14,50 \\
\hline BRS-191 & $12,55^{\mathrm{Bb}}$ & $9,45^{\mathrm{Bb}}$ & $39,71^{\mathrm{Aa}}$ & 20,57 \\
\hline Média & 16,12 & 16,96 & 25,60 & $\mathrm{CV}^{1}=17,2$ \\
\hline \multicolumn{5}{|l|}{ Mean } \\
\hline \multicolumn{5}{|c|}{ 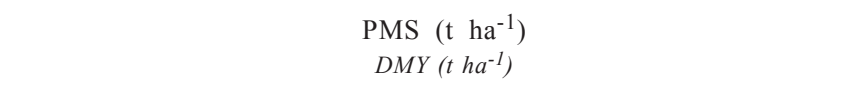 } \\
\hline Rumbosol-91 & $5,92^{\mathrm{Aa}}$ & $4,94^{\mathrm{Ba}}$ & $4,20^{\mathrm{Bb}}$ & 5,02 \\
\hline M-734 & $6,87^{\mathrm{Ba}}$ & $5,75^{\mathrm{Ba}}$ & $11,41^{\mathrm{Aa}}$ & 8,01 \\
\hline C-11 & $6,14^{\mathrm{Aa}}$ & $5,58 \mathrm{ABa}$ & $3,73^{\mathrm{Bb}}$ & 5,15 \\
\hline BRS-191 & $5,37^{\mathrm{Ba}}$ & $3,40^{\mathrm{Bb}}$ & $11,31^{\mathrm{Aa}}$ & 6,69 \\
\hline Média & 6,07 & 4,92 & 07,66 & $\mathrm{CV}^{1}=12,4$ \\
\hline Mean & & & & \\
\hline
\end{tabular}

1 CV $(\%)$ = Coeficiente de variação.

Médias seguidas por letras maiúsculas distintas na mesma linha e por letras minúsculas distintas na mesma coluna diferem $(P<0,05)$, respectivamente, entre épocas de semeadura e híbridos pelo teste Tukey.

${ }^{1} \mathrm{CV}(\%)=$ Coefficient of variation

Means followed by different capital letters in the same line and by different small letters in the same column differ $(P<0.05)$, respectively, among seeding dates and hybrids by Tukey test.

espécie vegetal ou cultivar, que apresenta diferença de crescimento ou produção em comparação a outra espécie ou outro cultivar sob condições de ambiente ideais ou adversas. Como a exigência entre cultivares da mesma espécie é distinta, é comum observar acúmulo de fitomassa diferenciado sob as mesmas condições de cultivo e para o mesmo ano agrícola. Além disso, o girassol pode produzir maior quantidade de fitomassa verde por unidade de área que o milho e sorgo (30 a $60 \mathrm{t} \mathrm{ha}^{-1} \mathrm{PMV}$ ). Todavia, dificilmente supera essas gramíneas em produtividade de MS (12 a $18 \mathrm{tha}^{-1}$ PMS).

Conforme Mello et al. (2004), a composição bromatológica da planta é tão importante quanto a contribuição de seus constituintes morfológicos. Logo, foram analisados os teores de MS, MO e PB (Tabela 6) e os componentes da parede celular (Tabela 7) do colmo, das folhas e do capítulo. A interação épocas de semeadura $\times$ híbridos de girassol foi significativa $(\mathrm{P}<0,05)$ para a maioria dos constituintes e variáveis. Não houve interação $(\mathrm{P}>0,05)$ apenas para os teores de $\mathrm{MO}$ e FDN do colmo, porém, seus teores de MO diferiram $(\mathrm{P}<0,05)$ entre épocas e híbridos, ao passo que os teores de FDN diferiram $(\mathrm{P}<0,05)$ somente entre épocas de semeadura.
Os híbridos M-734 e BRS-191 semeados em outubro apresentaram maiores teores de MS do colmo e, juntamente com o híbrido C-11 semeado em dezembro, maiores teores de MS do capítulo (Tabela 6). Na média, o híbrido BRS-191 apresentou os maiores teores de MS das folhas, que, neste experimento, variaram de 21,4 a 46,0\%; 27,1 a $74,3 \%$; e de 17,6 a $36,5 \%$, respectivamente, para colmo, folhas e capítulo. Amplitudes semelhantes foram relatadas por Evangelista \& Lima (2001), com valores de 19,1 a 29,3\% para o colmo; 28,4 a $80,1 \%$ para as folhas e 20,3 a $32,1 \%$ para o capítulo. Portanto, constata-se que o capítulo é o grande responsável pelos baixos teores de MS da cultura, pois, além de apresentar maior contribuição na planta (Tabela 4), atingiu os menores teores de MS (Tabela 6), seguido do colmo e das folhas.

Os teores de MO variaram de 90,9 a 96,0\% para o colmo, de 80,2 a $87,2 \%$ para as folhas e de 89,8 a $93,7 \%$ para o capítulo, de modo que os menores teores foram encontrados no híbrido C-11 para o colmo, no Rumbosol-91 semeado em novembro para as folhas e no BRS-191 semeado em novembro para o capítulo. Os teores de MO do colmo diminuíram da semeadura realizada em outubro para dezembro, provavelmente, em razão da elevação da temperatura nesse período (Tabela 2), aumentando a atividade microbiológica do solo e o metabolismo das plantas e, conseqüentemente, aumentando a mineralização da MO do solo e a absorção dos macro-nutrientes minerais pela planta, reduzindo suas concentrações de MO.

Os teores de PB oscilaram de 1,9 a 7,2\%, de 8,6 a 17,9\% e de 11,1 a $18,8 \%$, respectivamente, para colmo, folhas e capítulo. Todos os híbridos semeados em outubro apresentaram menores teores de PB no colmo e capítulo. No entanto, o híbrido C-11 semeado em dezembro apresentou maior teor de PB no colmo e, juntamente com o Rumbosol-91 semeado em dezembro, maiores teores de PB no capítulo. Nas folhas, os menores teores de PB foram obtidos no híbrido BRS-191 semeado em outubro e novembro, juntamente com o M-734 semeado em outubro. No entanto, o maior teor de PB foi encontrado para o híbrido BRS-191 semeado em dezembro. Ressalta-se que os teores de PB no colmo, nas folhas e no capítulo aumentaram da semeadura realizada em outubro para dezembro, podendo ser justificados, do mesmo modo que a MO, pelo aumento da temperatura no período, elevando a atividade microbiológica e, conseqüentemente, a mineralização do $\mathrm{N}$ orgânico do solo.

Quanto aos componentes da parede celular dos constituintes da planta (Tabela 7), os menores $(\mathrm{P}<0,05)$ teores de FDN e FDA no colmo foram encontrados na semeadura em novembro. O híbrido BRS-191 semeado em novembro apresentou menores $(\mathrm{P}<0,05)$ teores de FDN e FDA nas folhas. 
Tabela 6 - Teores médios de MS, MO e PB dos constituintes da planta de híbridos de girassol semeados em diferentes épocas Table 6 - Means values of DM, OM and CP of constituent of the plant of sunflower hybrids sowed in different dates

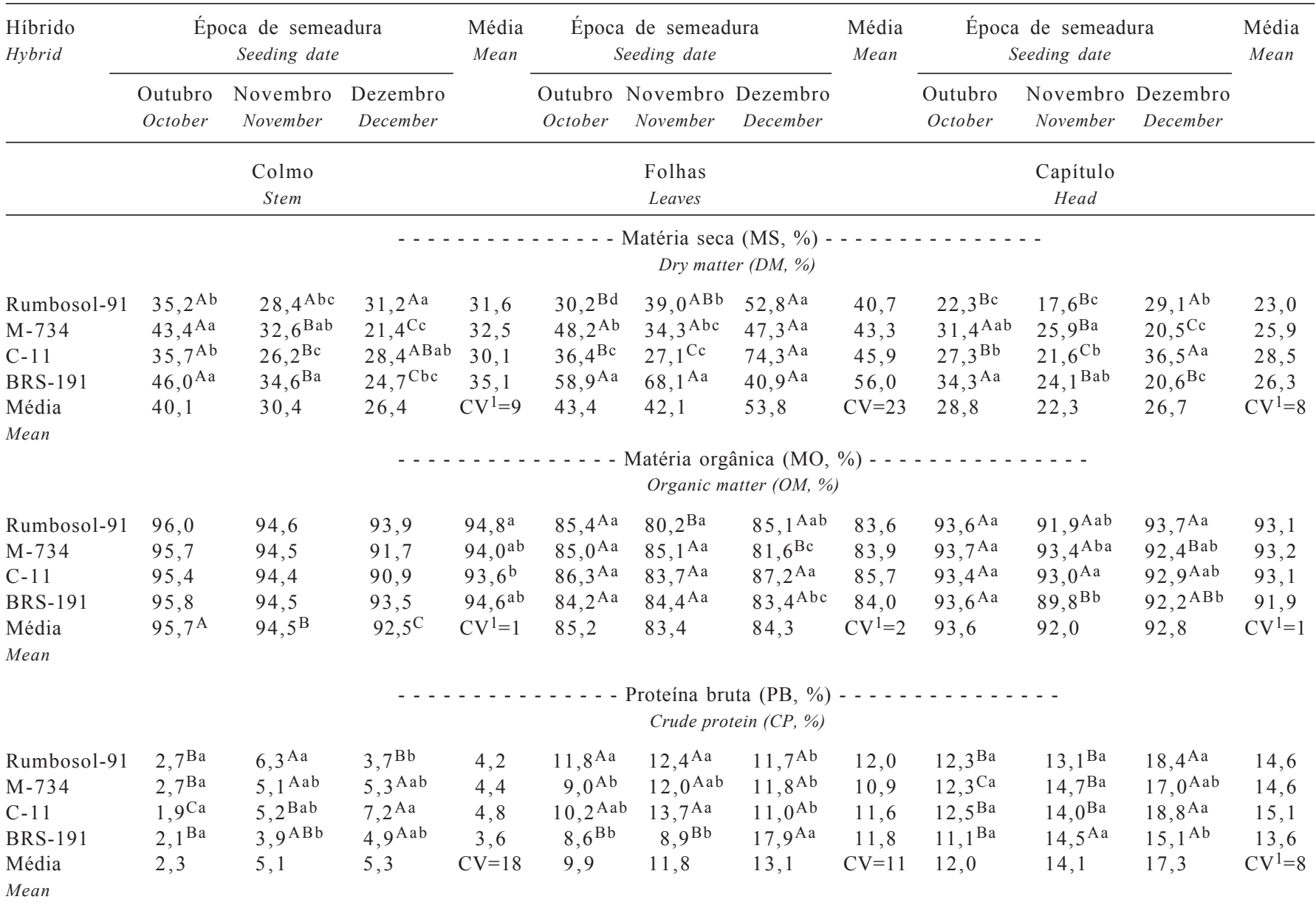

$1 \mathrm{CV}(\%)=$ Coeficiente de variação.

Médias seguidas por letras maiúsculas distintas na mesma linha e por letras minúsculas distintas na mesma coluna diferem $(P<0,05)$, respectivamente, entre épocas de semeadura e híbridos pelo teste Tukey.

${ }^{1} \mathrm{CV}(\%)=$ Coefficient of variation.

Means followed by different capital letters in the same row and by different small letters in the same column differ $(P<0.05)$, respectively, among seeding dates and hybrids by Tukey test.

Da mesma forma, o híbrido C-11 semeado em dezembro apresentou menores teores de FDN e FDA no capítulo. Destacam-se os elevados teores de FDN e FDA observados no colmo em relação às folhas e ao capítulo. Os maiores ou menores valores de FDN e FDA refletem, substancialmente, diferenças na deposição de celulose, uma vez que os reduzidos teores de hemicelulose da cultura e as concentrações de lignina não acompanham sua tendência.

Os teores de LDA no colmo, nas folhas e no capítulo foram menores em todos os híbridos semeados em outubro, supostamente em razão das menores temperaturas e do fotoperíodo durante essa época de semeadura, pois, conforme descrito por Mertens (1992), temperaturas elevadas aceleram o processo de maturação fisiológica, reduzindo o conteúdo celular e aumentando o processo de lignificação. Salientam-se os elevados teores de LDA encontrados no colmo, com valores oscilando entre 10,9 e $21,4 \%$, provavelmente em virtude da necessidade de uma estrutura mais rígida para suportar o peso do capítulo.
Os teores de PB aumentaram (Tabela 6) e os de FDN, FDA e LDA (Tabela 7) decresceram para colmo, folhas e capítulo, respectivamente. Comparando culturas de milho, sorgo e girassol, Mello et al. (2004) também notaram teores decrescentes de FDN $(59,7 ; 40,7$ e $31,6 \%)$ e FDA $(56,8 ; 34,7$ e 28,6\%) para colmo, folhas e capítulo em dois híbridos de girassol. Entretanto, o teor médio de LDA do colmo foi menor $(9,4 \%)$ que o da folha $(9,8 \%)$ e esses mesmos autores não encontraram teores crescentes de $\mathrm{PB}$ para colmo, folhas e capítulo, pois o teor de PB na folha foi superior $(12,6 \%)$ ao do capítulo $(12,0 \%)$, provavelmente pelo fato de a colheita da forragem ter sido feita em estádio mais imaturo.

A composição bromatológica da planta inteira pode ser visualizada na Tabela 8 . A interação épocas de semeadura $\times$ híbridos de girassol foi significativa $(\mathrm{P}<0,05)$ para os teores de MS e componentes da parede celular (FDN, FDA e LDA). Para os teores de $\mathrm{MO}$ e $\mathrm{PB}$, houve efeito $(\mathrm{P}<0,05)$ apenas da época de semeadura, de modo que os teores de MO diminuíram e os de PB aumentaram da semeadura em 
Tabela 7 - Componentes da parede celular dos constituintes da planta de híbridos de girassol semeados em diferentes épocas Table 7 - Cell wall components of constituent of the plant of sunflower hybrids sowed in different dates

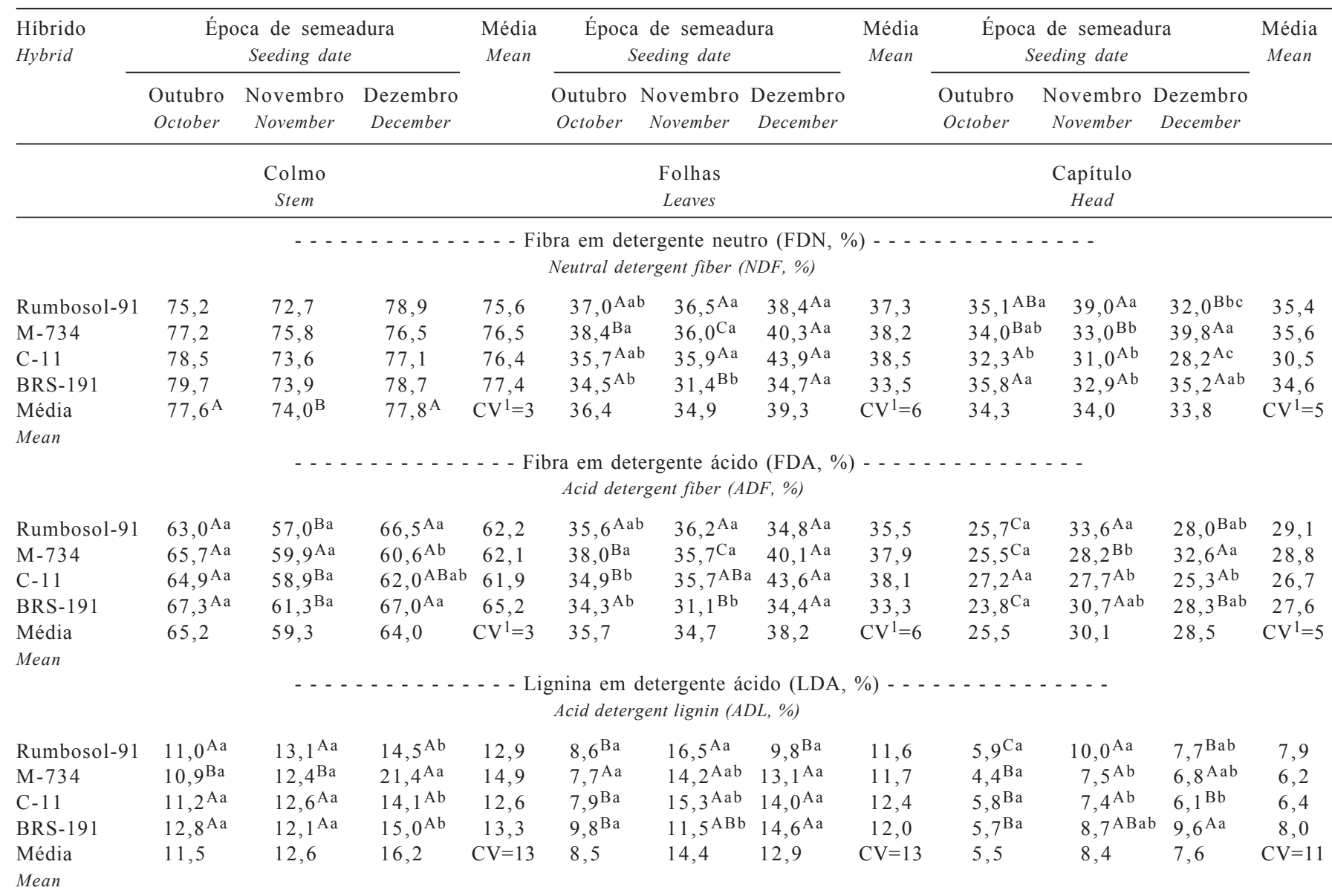

1 CV $(\%)$ = Coeficiente de variação.

Médias seguidas por letras maiúsculas distintas na mesma linha e por letras minúsculas distintas na mesma coluna diferem (P<0,05), respectivamente, entre épocas de semeadura e híbridos pelo teste Tukey.

${ }^{1} \mathrm{CV}(\%)=$ Coefficient of variation.

Means followed by different capital letters in the same row and by different small letters in the same column differ (P<0.05), respectively, among seeding dates and hybrids by Tukey test.

outubro para dezembro, provavelmente conseqüência do aumento da mineralização da MO do solo promovida pelo incremento da temperatura (Tabela 2) durante esse período. Os teores de PB variaram de 7 a $15,7 \%$, demonstrando a riqueza protéica da cultura.

Os teores de MS oscilaram de 23,2\% no híbrido Rumbosol-91 semeado em novembro a 47,9\% no híbrido C-11 semeado em dezembro. Entretanto, os teores de MS comumente indicados para ensilagem das culturas de milho e sorgo têm sido de 27 a 37\% (Paiva et al., 1978; Consentino, 1978; Boin, 1985; Nussio, 1990; Nussio, 1991; Nussio, 1992; Zago, 1991). McDonald et al. (1991) consideraram o baixo teor de MS, 17 a 18\% no estádio de grãos leitosos, como fator limitante da cultura, e que esse baixo teor não está apenas relacionado a colheitas precoces, mas também à utilização de cultivares que mantêm elevado teor de umidade, mesmo em estágios avançados de maturidade físiológica. Valores semelhantes aos obtidos nesse estudo foram relatados por Evangelista \& Lima (2001), de 15,4 a 47,8\% de
MS na silagem de girassol, considerados satisfatórios para a cultura. Mello et al. (2004) ensilaram o girassol com teores de 20,1 e 21,8\% MS sem comprometer a qualidade fermentativa da silagem, todavia, não avaliaram perdas por lixiviação dos nutrientes na forma de efluentes, as quais podem chegar a $8 \%$ quando o teor de MS é inferior a 30\% (Consentino, 1978). Por outro lado, Kung \& Shaver (2005) relataram que, para o processo fermentativo ser comprometido e os valores de $\mathrm{pH}$ serem elevados $(\mathrm{pH}>4,4)$, é necessário que a MS da forrageira ensilada seja superior a 50\%. Assim, embora os teores de MS obtidos nesse estudo estejam fora da faixa normalmente indicada pela literatura para as culturas de milho e sorgo, podem ser considerados satisfatórios para a cultura do girassol.

Analisando os componentes da parede celular da planta inteira, observa-se que os teores de FDN e FDA foram maiores no híbrido M-734 semeado em outubro. Por outro lado, os menores teores de FDN e FDA foram observados na semeadura em novembro, observando-se que a cultura 
Tabela 8 - Composição bromatológica da planta inteira de híbridos de girassol (Helianthus annuus L.) semeados em diferentes épocas

Table 8 - Bromatological composition of the whole plant of sunflower hybrids (Helianthus annuus L.) sowed in different dates

\begin{tabular}{|c|c|c|c|c|}
\hline \multirow[t]{2}{*}{$\begin{array}{l}\text { Híbrido } \\
\text { Hybrid }\end{array}$} & \multicolumn{3}{|c|}{$\begin{array}{c}\text { Época de semeadura } \\
\text { Seeding date }\end{array}$} & \multirow[t]{2}{*}{$\begin{array}{l}\text { Média } \\
\text { Mean }\end{array}$} \\
\hline & $\begin{array}{l}\text { Outubro } \\
\text { October }\end{array}$ & $\begin{array}{l}\text { Novembro } \\
\text { November }\end{array}$ & $\begin{array}{c}\text { Dezembro } \\
\text { December }\end{array}$ & \\
\hline \multicolumn{5}{|c|}{$\begin{array}{c}\text { Matéria seca }(\%) \\
\text { Dry matter (\%) }\end{array}$} \\
\hline Rumbosol-91 & $28,7^{\mathrm{Ac}}$ & $23,2^{\mathrm{Ab}}$ & $33,5^{\mathrm{Ab}}$ & 28,5 \\
\hline M-734 & $36,5^{\mathrm{Aab}}$ & $27,2^{\mathrm{Bab}}$ & $23,7^{\mathrm{Bb}}$ & 29,1 \\
\hline C- 11 & $34,6^{\mathrm{Bb}}$ & $25,2^{\mathrm{Cb}}$ & $47,9^{\mathrm{Aa}}$ & 35,9 \\
\hline BRS-191 & $39,2^{\mathrm{Aa}}$ & $32,3^{\mathrm{ABa}}$ & $26,2^{\mathrm{Bb}}$ & 32,6 \\
\hline Média & 34,7 & 27,0 & 32,8 & $\mathrm{CV}^{1}=10,4$ \\
\hline
\end{tabular}

Mean

Matéria orgânica (\%)

Organic matter $(\%)$

$\begin{array}{llllc}\text { Rumbosol-91 } & 92,8 & 91,1 & 92,3 & 92,1 \\ \text { M-734 } & 93,4 & 90,8 & 91,1 & 91,8 \\ \text { C-11 } & 92,8 & 90,4 & 91,2 & 91,5 \\ \text { BRS-191 } & 92,9 & 90,8 & 91,0 & 91,6 \\ \text { Média } & 93,0^{\mathrm{A}} & 90,8^{\mathrm{B}} & 91,4^{\mathrm{B}} & \mathrm{CV}^{1}=0,7 \\ \text { Mean } & & & & \end{array}$

Proteína bruta $(\%)$

Crude protein (\%)

\begin{tabular}{llllc} 
Rumbosol-91 & 9,4 & 14,4 & 14,5 & 12,8 \\
M-734 & 7,0 & 14,2 & 14,8 & 12,0 \\
C-11 & 9,1 & 14,0 & 15,7 & 12,9 \\
BRS-191 & 9,1 & 13,7 & 14,0 & 12,3 \\
Média & $8,7^{\mathrm{B}}$ & $14,1^{\mathrm{A}}$ & $14,8^{\mathrm{A}}$ & $\mathrm{CV}^{1}=10,4$ \\
Mean & \multicolumn{5}{c}{} \\
& \multicolumn{5}{c}{ FDN (\%) } \\
\multicolumn{5}{c}{ NDF (\%) } \\
Rumbosol-91 & $48,7^{\mathrm{Ab}}$ & $40,6^{\mathrm{Ba}}$ & $41,6^{\mathrm{Bb}}$ & 43,6 \\
M-734 & $59,7^{\mathrm{Aa}}$ & $39,8^{\mathrm{Ba}}$ & $39,5^{\mathrm{Bb}}$ & 46,3 \\
C-11 & $48,0^{\mathrm{Ab}}$ & $36,8^{\mathrm{Ba}}$ & $39,3^{\mathrm{Bb}}$ & 41,4 \\
BRS-191 & $53,8^{\mathrm{Aab}}$ & $40,9^{\mathrm{Ba}}$ & $46,4^{\mathrm{ABa}}$ & 47,0 \\
Média & $52,5^{5}$ & 39,5 & 41,7 & $\mathrm{CV}^{1}=4,5$
\end{tabular}

Mean

FDA $(\%)$

$A D F(\%)$

$\begin{array}{llllc}\text { Rumbosol-91 } & 40,3^{\mathrm{Abc}} & 38,8^{\mathrm{Aa}} & 39,3^{\mathrm{Aa}} & 39,5 \\ \text { M-734 } & 47,2^{\mathrm{Aa}} & 36,2^{\mathrm{Ba}} & 39,0^{\mathrm{Ba}} & 40,8 \\ \text { C-11 } & 38,9^{\mathrm{Ac}} & 35,3^{\mathrm{Aa}} & 33,6^{\mathrm{Ab}} & 35,9 \\ \text { BRS-191 } & 45,0^{\mathrm{Aab}} & 34,8^{\mathrm{Ba}} & 38,4^{\mathrm{ABab}} & 39,4 \\ \text { Média } & 42,8 & 36,3 & 37,6 & \mathrm{CV}^{1}=4,7\end{array}$

Mean

LDA $(\%)$

$A D L(\%)$

$\begin{array}{lcccc}\text { Rumbosol-91 } & 8,8^{\mathrm{Ab}} & 10,6^{\mathrm{Aa}} & 9,9^{\mathrm{Aab}} & 9,8 \\ \text { M-734 } & 8,8^{\mathrm{Ab}} & 9,4^{\mathrm{Aa}} & 6,5^{\mathrm{Bc}} & 8,2 \\ \text { C-11 } & 6,9^{\mathrm{Bb}} & 9,3^{\mathrm{Aa}} & 9,0^{\mathrm{ABb}} & 8,4 \\ \text { BRS-191 } & 12,4^{\mathrm{Aa}} & 9,5^{\mathrm{Ba}} & 10,6^{\mathrm{ABa}} & 10,8 \\ \text { Média } & 9,2 & 9,7 & 9,0 & \mathrm{CV}^{1}=7,7\end{array}$

Mean

${ }^{1} \mathrm{CV}(\%)=$ Coeficiente de variação

Médias seguidas por letras maiúsculas distintas na mesma linha e por letras minúsculas distintas na mesma coluna diferem $(P<0,05)$, respectivamente, entre épocas de semeadura e híbridos pelo teste Tukey.

${ }^{1} \mathrm{CV}(\%)=$ Coefficient of variation.

Means followed by different capital letters in the same line and by different small letters in the same column differ $(P<0.05)$, respectively, among seeding dates and hybrids by Tukey test. é praticamente desprovida de hemicelulose e apresenta elevados teores de FDA (FDA > 30\%), que são correlacionados negativamente à digestibilidade.

Os teores de LDA oscilaram de 6,5 a 12,4\%, de modo que os híbridos M-734 semeado em dezembro e C-11 semeado em outubro apresentaram os menores $(\mathrm{P}<0,05)$ teores. Em contrapartida, o híbrido BRS-191 semeado em outubro apresentou o maior $(\mathrm{P}<0,05)$ teor de LDA, demonstrando elevados teores de lignina, os quais podem reduzir o consumo voluntário pelo animal. Além disso, a lignina pode limitar a extensão de digestão dos demais componentes da parede celular, dependendo de sua concentração e composição estrutural (Jung, 1989).

\section{Conclusões}

A interação épocas de semeadura $x$ híbridos de girassol foi significativa para a maioria das características fenológicas, produtivas e qualitativas, que foram marcadamente influenciadas pelos fatores meteorológicos temperatura, insolação e fotoperíodo.

A semeadura em outubro (antecipada) proporcionou ciclo, porte e teores de matéria orgânica maiores, porém diâmetro, participação de capítulo e teores de proteína bruta e lignina menores que a semeadura em dezembro (tardia).

Visando à produção de silagem de alta qualidade, o híbrido M-734 semeado em dezembro apresentou melhor relação entre fenologia, produtividade e composição bromatológica.

\section{Literatura Citada}

ASSOCIATION OF OFFICIAL ANALYTICAL CHEMISTS - AOAC. Official methods of analysis. 16.ed. Washington, DC.: AOAC, 1995. 2000p.

BANYS, V.L.; TIESENHAUSEN, I.M.E.V. von; FALCO, J.E. et al. Consórcio milho-girassol: características agronômicas. Ciência e Agrotecnologia, v.20, n.1, p.84-89, 1996.

BARNI, N.A.; BERLATO, M.A.; SANTOS, A.O. et al. Análise de crescimento do girassol em resposta a cultivares, níveis de adubação e épocas de semeadura. Pesquisa Agropecuária Gaúcha, v.1, n.2, p.167-184, 1995a.

BARNI, N.A.; BERLATO, M.A.; BERGAMASCHI, H. et al. Rendimento máximo do girassol com base na radiação solar e temperatura: II. produção de fitomassa e rendimento de grãos. Pesquisa Agropecuária Gaúcha, v.1, n.2, p.201-216, 1995b.

BOIN, C. Utilização de volumoso para gado de corte. In: SIMPÓSIO DE GADO DE CORTE, 1., 1985, São Paulo. Anais... São Paulo: 1985. v.1, p.38-61.

BRASIL, Ministério da Agricultura. Levantamento de reconhecimento dos solos do estado do Rio Grande do Sul. Rio de Janeiro: Departamento Regional de Pesquisa Agropecuária: Divisão de Pesquisas Pedológicas, 1973. 431p. (Boletim Técnico, 30).

COMISSÃO DE FERTILIDADE DO SOLO RS/SC. Recomendações de adubação e calagem para os Estados do Rio Grande do Sul e Santa Catarina. 3.ed. Passo Fundo: Sociedade Brasileira de Ciência do Solo, Núcleo Regional Sul/EMBRAPA - CNPT. 1995. 223p. 
CONSENTINO, J.R. Fermentações da silagem. Zootecnia, v.16, n.1, p.57-61, 1978.

DEMARCHI, J.J.A.A. A cultura do girassol para produção de silagens - parte 1 de 2 - características agronômicas. Disponível em: <http://www.beefpoint.com.br>. Acesso em: 24/11/2000.

DUDIENAS, C.; UNGARO, M.R.G.; MORAES, S.A. Alternaria disease development under tropical conditions. Helia, v.21, n.29, p.63-72, 1998 .

EMPRESA BRASILEIRA DE PESQUISA AGORPECUÁRIA EMBRAPA. Centro Nacional de Pesquisa de Solos. Sistema brasileiro de classificação de solos. Brasília: EMBRAPA, Rio de Janeiro, 1999. 412p.

EVANGELISTA, A.R.; LIMA, J.A. Utilização de silagens de girassol na alimentação animal. In: SIMPÓSIO SOBRE PRODUÇÃO E UTILIZAÇÃO DE FORRAGENS CONSERVADAS, 1., 2001, Maringá. Anais... Maringá: Universidade Estadual de Maringá, 2001. p.177-217.

FAGERIA, N.K. Solos tropicais e aspectos fisiológicos das culturas. Brasília: EMBRAPA-CNPAF, 1989. 425p.

FONSECA, F.S.; GARCIA, S.M.; CARRER, C.R.O. et al. Estudo comparativo da matéria seca, proteína bruta e alguns parâmetros de crescimento de duas cultivares de girassol (Helianthus annuus L.) para silagem. In: REUNIÃO ANUAL DA SOCIEDADE BRASILEIRA DE ZOOTECNIA, 37., 2000, Viçosa, MG. Anais... Viçosa, MG: Sociedade Brasileira de Zootecnia, 2000. CD-ROM

GOERING, H.K.; Van SOEST, P.J. Forage fiber analysis: apparatus, reagents, procedures and some applications. Washington, D.C.: United States Department of Agriculture, 1970. 20p. (USDA, Agricultural Handbook, 379).

KUNG, L.; SHAVER, R. Interpretation and use of silage fermentation analysis reports: In: FOCUS ON FORAGE, 3, 2001, Madison. Anais eletrônicos... Madison: University of Wisconsin, Team Forage, v.3, n.13, 2001. Disponível em: $<$ http://www.uwex.edu/ces/crops/uwforage/focusonforage.htm $>$. Acesso em: 22 jan. de 2005.

LEITE, R.M.V.B.C.; BRIGHENTI, A.M.; CASTRO, C. Girassol no Brasil. Londrina: Embrapa Soja, 2005. 613p.

MARIN, F.R.; SENTELHAS, P.C.; UNGARO, M.R.G. Perda de rendimento potencial da cultura do girassol por deficiência hídrica, no Estado de São Paulo. Scientia Agrícola, v.57, n.1, p. $1-6,2000$

MCDONALD, P.; HENDERSON, A.R.; HERON, S. The biochemistry of silage. Marlow: Chalcombe Publications, 1991. 340p.

MELLO, R.; NÖRNBERG, J.L.; ROCHA, M.G. Potencial produtivo e qualitativo de híbridos de milho, sorgo e girassol para ensilagem. Revista Brasileira de Agrociência, v.10, n.1, p. 87-95, 2004

MERTENS, D.R. Analysis of fiber in feeds and its use in feed evaluation and ration formulation. In: REUNIÃO ANUAL DA SOCIEDADE BRASILEIRA DE ZOOTECNIA, 29., SIMPÓSIO INTERNACIONAL DE RUMINANTES, 1992, Lavras, MG. Anais... Lavras: Sociedade Brasileira de Zootecnia, 1992. p.1-32.

MOREnO, J.A. Clima do Rio Grande do Sul. Porto Alegre: Secretaria da Agricultura, 1961. 41p.

NUSSIO, L.G. Milho e sorgo na produção de silagem. In: PEIXOTO, A.M.; MOURA, J.C.; FARIA, V.P. (Eds.) Produção de alimentos volumosos para bovinos. Piracicaba: Fundação de Estudos Agrários Luiz de Queiroz, 1990. p.89-205.
NUSSIO, L.G. Cultura de milho para a produção de silagem de alto valor alimentício. In: SIMPÓSIO DE NUTRIÇÃO DE BOVINOS, 4., 1991, Piracicaba. Anais... Piracicaba: Fundação de Estudos Agrários Luiz de Queiroz, 1991. p.59-168.

NUSSIO, L.G. Produção de silagem de alta qualidade. In: CONGRESSO NACIONAL DE MILHO E SORGO, 19, 1992, Porto Alegre. Conferências... Porto Alegre: SSA/SCT/ABMS/EMATER-RS/ EMBRAPA-CNPMS, p.155-175, 1992.

PAIVA, J.A.J.; PIZARRO, E.A.; RODRÍGUEZ, N.M. et al. Qualidade da silagem da região metalúrgica de Minas Gerais. Arquivo Brasileiro de Medicina Veterinária e Zootecnia, v.30, p.8188, 1978 .

REZENDE, A.V.; EVANGELISTA, A.R.; SIQUEIRA, G.R. et al. Efeito da densidade de semeadura sobre a produtividade e composição bromatológica de silagens de girassol (Helianthus annuus L.). Ciência e Agrotecnologia, p.1672-1678, 2003.

SANTOS, A.C.; ANDRADE, A.P.; LIMA, J.R.S. et al. Variabilidade temporal da precipitação pluvial: nível de nitrogênio no solo e produtividade de cultivares de girassol. Ciência Rural, v.32, n. 5, p.757-764, 2002.

STATISTICAL ANALYSIS SYSTEM - SAS. SAS System for Windows. Cary: SAS Institute Inc., v.8.0, 1999.

SILVA, P.R.F.; MUNDSTOCK, C.M. Época de semeadura. In: Girassol: indicações para o cultivo no Rio Grande do Sul. 3.ed. Porto Alegre: Universidade Federal do Rio Grande do Sul, p.1318,1990

SILVA, P.R.F.; RIZZARDI, M.A. Resposta de cultivares de girassol à densidade de plantas em duas épocas de semeaduras. II. características associadas a colheita. Pesquisa Agropecuária Brasileira, v.28, n.6, p.689-700, 1993.

TOMICH, T.R.; RODRIGUES, J.A.S.; GONÇALVES, L.C. et al Potencial forrageiro de cultivares de girassol produzidos na safrinha para ensilagem. Arquivos Brasileiro de Medicina Veterinária e Zootecnia, v.55, n.6, p.756-762, 2003.

TOSI, H.; SILVEIRA, A.C.; FARIA, V.P. et al. Avaliação do girassol (Helianthus annus) como planta para a ensilagem. Revista Brasileira de Zootecnia, v.4, p.39-48, 1975.

UNGARO, M.R.G.; NOGUEIRA, S.S.S.; NAGAI, V. Parâmetros fisiológicos, produção de aquênios e fitomassa de girassol em diferentes épocas de cultivo. Bragantia, v.59, n.2, p.205211,2000

Van SOEST, P.J.; ROBERTSON, J.B.; LEWIS, B.A. Methods for dietary fiber, neutral detergent fiber, and nonstarch polysaccharides in relation to animal nutrition. Journal of Dairy Science, v.74, n.10, p.3583-3597, 1991 .

ZAFFARONI, E.; GRIGOLO, S.C. Determinação da época de plantio do girassol na região sul do Rio Grande do Sul. Revista Brasileira de Agrociência,v.2, n.2, p.138-142, 1998.

ZAGO, C.P. Cultura do sorgo para produção de silagem de alto valor nutritivo. In: SIMPÓSIO SOBRE NUTRIÇÃO DE BOVINOS, 4., 1991, Piracicaba. Anais... Piracicaba: Fundação de Estudos Agrários Luiz de Queiroz, 1991. p.169-217. 